\title{
MATA PELAJARAN SEJARAH SMA DI KURIKULUM 2013
}

\author{
Febbrizal ${ }^{1}$, Aman $^{2}$ \\ 1,2Pascasarjana Universitas Negeri Yogyakarta \\ 1,2Jalan Colombo, Daerah Istimewa Yogyakarta 55281 \\ Email: febbriza192.2017@student.uny.ac.id1, aman@uny.ac.id ${ }^{2}$
}

\begin{abstract}
Abstrak:
Penelitian ini bertujuan untuk menganalisis materi pelajaran sejarah di kurikulum 2013 jenjang Sekolah Menengah Atas (SMA/sederajat) dan mengetahui kedudukan kajian sejarahnya dalam bagian yang menjadi komponen krusial kurikulum 2013. Metode yang digunakan adalah studi kepustakaan (research library) yang tidak hanya menelusuri sumber pustaka yang sesuai dengan kajian penelitian namun juga menjadikan data untuk penulisan. Hasil penelitian menunjukan posisi mata pelajaran sejarah membentuk dua cabang besar pada sejarah Indonesia (wajib) yang digunakan oleh semua kelompok peminatan (IPA dan IPS) dan cabang sejarah peminatan (IPS) yang ruang lingkupnya lebih komprehensif. Kelompok sejarah wajib dan peminatan pada evolusi standar kompetensi (SK) pada kurikulum sebelumnya menjadi kompetensi inti (KI) yang menunjukan perbaikan tujuan pencapaian kompetensi.
\end{abstract}

\begin{abstract}
:
The purpose of this research was to analyze the study of the history subjects of the 2013 curriculum for high school (or equivalent), and then look at the position of their historical studies in the part which is a crucial component of the 2013 curriculum. The research library is not only tracing the source of the literature. according to research studies but also makes it data for writing. The results showed that the position of historical subjects formed two major branches in Sejarah Indonesian (wajib) used by all specialization groups (IPA and IPS) and Sejarah Peminatan (IPS) branches that were more comprehensive in scope. It was required to the history group and specialization as the evolution of competency standards (SK) which was in the previous curriculum became core competencies (KI) which indicated the improvement of the competency achievement goals.
\end{abstract}

Kata kunci:

Sejarah Wajib, Sejarah Peminatan, Kurikulum 2013

How to Cite: Febbrizal, \& Aman. (2019). Mata Pelajaran Sejarah SMA di Kurikulum 2013. Lentera Pendidikan : Jurnal Ilmu Tarbiyah dan Keguruan, 22(2), 203-212.

\section{PENDAHULUAN}

Sejak berlakunya kurikulum 2013 mengantikan kurikulum berbasis kompetensi sebagai uji coba pada tahun pelajaran 2013/2014 yang diterapkan di sejumlah sekolah dan kemudian secara resmi digunakan pada tahun pelajaran 2014/2015 sesuai dengan Peraturan Menteri Pendidikan dan Kebudayaan Nomor 160 Tahun 2014 tentang Pemberlakuan Kurikulum Tahun 2006 dan Kurikulum 2013, berdasarkan aturan tersebut kurikulum 2013 secara resmi berlaku 12 Desember 2014 (Rochgiyanti, 2014). 
Pada pengembangnya kurikulum 2013 mengacu 4 standar dari 8 standar nasional pendidikan yakni: (1) standar isi, (2) standar proses, (3) standar kompetensi lulusan, dan (3) standar penilaian. Perubahan paling mendasar dari kurikulum sebelumnya (KTSP) adalah: (1) konsep kurikulum baik sebagai materi, produk, dan proses kontekstual yang menyesuaikan tantangan zaman yang berkembang pesat, dalam artian ada keseimbangan hardskill dan softskill dari SKL, standar isi, standar proses, dan standar penilaian; (2) buku yang berbasis pada aktivitas dan tematik terpadu (untuk $\mathrm{SD})$; (3) proses pembelajaran dengan pendekatan saintifik dan; (4) proses penilaian yang mendukung kreatifitas (Subandi, 2014). Perubahan tersebut bila diteliti mampu mengakomodir tujuan pendidikan sejarah yang unik, yaitu sebagai medium untuk mengembangkan potensi peserta didik terhadap nilai-nilai bangsa dalam konteks ruang dan waktu yang dinamis dan sebagai medium mengembangkan keilmuan sejarah itu sendiri (Hasan, 2007). Mata pelajaran sejarah dalam kurikulum 2013 turut mendapat porsi yang lebih dengan menambah dan membagi jam pada sejarah kelompok peminatan (hanya untuk IPS) dan mata pelajaran sejarah Indonesia yang diwajibkan bagi kelompok peminatan IPA dan IPS.

Sejalan dengan tantangan masa depan yang mendorong pengembangan kurikulum 2013 terkait globalisasi (ASEAN Community, APEC, CAFTA), einvoremental, perkembangan teknologi, ilmu dan konvergensinya, ekonomi smart, industri kreatif \& budaya, pergeseran kekuatan ekonomi dunia, pengaruh dan imbas tekno-sains (Paparan Wamendikbud, 14 Januari 2014), tujuan pendidikan sejarah menjembatani konsep ruang dan waktu terakit kegiatan belajar dari kesalahan masa lalu, memperbaiki hari ini, untuk kemudian mencapai harapan atau target yang dicanangkan dalam menghadapi tantangan masa depan seperti yang dipaparkan oleh kemendikbud.

Pada dekade terakhir, di tengah arus perubahan zaman yang begitu cepat dari sisi teknologi dan ilmu pengetahuan yang membawa umat manusia ke dalam masamasa puncak perkembangannya. Arus teknologi menyempitkan dunia dari sebelumnya yang pernah terjadi, kini orang-orang tidak kesulitan menghubungi kolega atau sanak familinya di wilayah yang beratus-ratus dan beribu-ribu kilometer jaraknya. Bahkan untuk melakukan perjalanan jarak jauh lintas benua dapat diperpendek masanya dari berbulan-bulan ke hitungan hari saja. Arus teknologi juga membawa budaya baru yang dominan dapat menyebar secara masif tanpa rentang yang lama untuk sampai ke satu negara ke negara lain bahkan satu benua ke benua lainnya.

Saat ini fenomena global terkait kecepatan arus informasi, ekonomi, sosial, budaya bahkan politik yang merajalela di belahan bumi yang terjangkau oleh perangkat teknologi sebagai globalisasi. Jika dahulu fenomena globalisasi yang membawa pengaruh dari satu negara ke negara lain dari satu benua ke benua lainnya membutuhkan jeda waktu yang panjang untuk sampai di tempat tersebut. Namun, melalui arus informasi yang termaktub dalam internet semuanya hanya selang beberapa kedipan mata saja. 
High technology tentunya bagai pisau bermata dua yang memiliki potensi negatif dan positif. Dalam banyak hal, terdapat banyak keuntungan yang dirasakan oleh manusia. Namun, sisi negatif yang ditimbulkan akibat hal tersebut telah memasuki tatanan dan taraf hidup pada masyarakat. Sebutan generasi millineal yang lahir dari konsep globalisasi pada high technology di era ini membawa kesenjangan dalam kultur sosial setempat. Terbukanya informasi yang luas dalam perangkat teknologi berbasis internet melahirkan generasi-generasi yang memiliki tambahan dunia baru (maya) selain dunia nyata tempat mahluk sosial berinteraksi.

Imbas dari hal tersebut adalah berkurangnya interaksi antar sesama atau lingkungan sosial, maka tak heran dengan terbaginya sudut pandang dunia dalam nyata dan maya memunculkan problem-problem sosial, yakni terkait degradasi karakter (dalam hal ini moral) masyarakat terutama generasi millineal dalam sudut pandang tatanan sosial, misalnya sikap acuh tak acuh, etika pergaulan yang bebas, penyerapan nilai-nilai asing yang tidak sesuai dengan konsep masyarakat sosial setempat. Generasi millineal merupakan generasi yang memasuki tahap-tahap perkembangan paling signifikan dalam dalam dirinya, tak terkecuali siswa Sekolah Menengah Atas di Indonesia.

Berdasarkan Pasal 3 Undang-Undang nomor 20 Tahun 2003 tentang Sistem Pendidikan Nasional yang berbunyi, (Mastur, 2017)

"Pendidikan nasional berfungsi mengembangkan kemampuan membentuk watak serta peradaban bangsa yang bermartabat dalam rangka mencerdaskan kehidupan bangsa, bertujuan untuk berkembangnya potensi peserta didik agar menjadi manusia yang beriman dan bertakwa kepada Tuhan Yang Maha Esa, berakhlak mulia, sehat, berilmu, cakap, kreatif, mandiri, dan menjadi warga negara yang demokratis serta bertanggung jawab."

Makna dari undang-undang tersebut adalah pendidikan nasional menghendaki terciptanya generasi bangsa yang berkarakter religius, berakhlak mulia, cendikia, mandiri, dan demokratis. Pada tahun 2010 Kementrian Pendidikan Nasional mencanangkan pembangunan karakter bangsa dengan empat nilai utama yakni jujur, cerdas, tangguh dan peduli. Sejalan dengan hal tersebut munculnya perubahan kurikulum dari KTSP menjadi Kurikulum 2013 tentu merubah arus pengetahuan terutama sejarah untuk Sekolah Menengah Atas atau sederajat.

Hasil penelitian yang dilakukan oleh Sardiman (2015a), tentang “Menakar Posisi Sejarah Indonesia Pada Kurikulum 2013" bertujuan untuk mengetahui posisi mata pelajaran sejarah dalam kurikulum 2013 dan peranannya dalam pembentukan karakter bangsa. Hasil penelitian tersebut menunjukan posisi mata pelajaran sejarah dalam kurikulum 2013 telah difungsikan untuk membentuk karakter bangsa dan menjadi alat pemersatu rasa kebangsaan dan cinta tanah air.

Sejalan dengan penelitian yang dilakukan oleh Sardiman tersebut, skripsi yang ditulis oleh Haniah (2017) tentang "Pelaksanaan Pembelajaran Sejarah dengan Kurikulum 2013", Sutarman (2015) tentang “Implementasi Kurikulum 2013 dalam Pembelajaran Sejarah di SMAN 1 Rembang Tahun Ajaran 2014/2015" dan skripsi Sayyidah (2014) tentang “Implementasi Kurikulum 2013 Mata Pelajaran Sejarah Wajib 
Kelas X di SMA MTA Surkarta Tahun Ajaran 2014/2015". Inti dari ketiganya adalah pelaksanaan kegiatan pembelajaran sejarah berbasis kurikulum 2013 telah diterapkan di sekolah masing-masing tempat penelitian penulis, perbedaanya terkait pada pemahaman dan kendala yang ditemui oleh stake holder masing-masing sekolah untuk menerima konsep kurikulum 2013 yang dilaksanakan dalam pembelajaran sejarah.

Sulasman (2014) mengungkapkan pengertian sejarah secara umum sebagai peristiwa yang terjadi dalam dimensi waktu, baik satu abad maupun satu detik yang lalu yang melekat pada kehidupan manusia. Pembahasan tentang sejarah tidak dapat dipisahkan dari cerita tentang peristiwa/kejadian dalam dimensi waktu atau masa yang telah berlalu, yang disusun secara kronologis. Luasnya pembatasan masa lampau tersebut sehingga para ahli sepakat bahwa zaman sejarah bermula ketika bukti-bukti tertulis ditemukan (Kuntowijoyo, 2008). Berdasarkan kedua pendapat tersebut sejarah menitikberatkan peristiwa dalam ruang dan waktu yang telah berlalu untuk dipahami sebagai bagian kehidupan umat manusia untuk diambil pelajaran ataupun membentuk keyakinan umat manusia menghadapi tantangan hari ini dan masa yang akan datang.

Sementara itu dalam pembelajaran sejarah, Sardiman (2015a) mengungkapkan pembelajaran sejarah sebagai alur proses yang memantik pekembangan dan mengasah potensi serta kepribadian peserta didik melalui pesan-pesan sejarah agar menjadi warga bangsa yang arif dan bermartabat. Sulasman (2014) mengungkapkan objek materi sejarah dan ilmu sejarah sebagai peristiwa yang telah terjadi di masa lampau yang menyimpan makna dan hikmah besar bagi kehidupan manusia pada masa yang akan datang. Berdasarkan dua pendapat sebelumnya, tujuan penulisan ini ialah mengetahui kajian sejarah dalam kurikulum 2013 baik kedudukan maupun proporsionalnya. Dalam pembahasan selanjutnya akan dikupas mengenai posisi mata pelajaran sejarah (baik wajib maupun peminatan), ruang lingkup kajian sejarah, tujuan \& muatan isi dan desain pembelajaran sejarah serta perubahan KI dan KD dalam kurikulum 2013.

\section{METODE PENELITIAN}

Penelitian ini merupakan penelitian deskripsi yang bertujuan untuk menganalisis mata pelajaran sejarah di kurikulum 2013. Metode deskripsi analisis ialah suatu langkah yang mampu menjelaskan atau memberikan penjabaran dari objek yang dianalisis melalui data atau sampel yang dihimpun sesuai dengan keadaan yang sebenarnya (Sugiyono, 2009). Untuk pengumpulan sumber menekankan pada studi pustaka (research library), Zed (2004) berpendapat bahwa hampir setiap jenis penelitian membutuhkan studi pustaka. Meskipun orang sering membedakan riset kepustakaan dan riset lapangan. Secara substansi perbedaanya adalah pada tujuan, fungsi dan kedudukan studi pustaka dalam masing-masing penelitian tersebut. Dalam riset lapangan, penelusuran pustaka terutama dimaksudkan untuk tindakan pertama dalam menyiapkan kerangka penelitian (research design) atau proposal untuk memperoleh informasi penelitian sejenis, memperdalam kajian teoritis atau mempertajam metodologi. Sedangkan dalam riset pustaka, penelusuran pustaka lebih dari sekedar 
melayani fungsi-fungsi yang telah disebutkan sebelumnya. Riset pustaka sekaligus memanfaatkan sumber perpustakaan untuk memperoleh data penelitiannya.

\section{HASIL PENELITIAN DAN PEMBAHASAN}

\section{Posisi Mata Pelajaran Sejarah Dalam Kurikulum 2013}

Jika dianalisis secara mendalam isi Kepmen 59/2014 Pasal 5 ayat 1, maka terlihat jelas bahwa mata pelajaran sejarah wajib lebih menekankan pada bagaimana anak belajar sejarah menjadi anak Indonesia. Kurikulum 2013 selain menempatkan mata pelajaran sejarah pada kelompok mata pelajaran wajib serta peminatan, bila dilihat dari porsi dan frekuensi pertemuan dan jam pelajaran, pelajaran sejarah diberikan porsi lebih dibandingkan porsi pembelajaran pada kurikulum sebelumnya. Jika sebelumnya guru-guru sejarah mengeluhkan kurangnya jam pelajaran sejarah sehingga guru kurang maksimal dalam menyampaikan materi pelajaran, maka dalam kurikulum sejarah 2013 akan ditemukan hal yang berbeda. Kurikulum sejarah menjadikan pelajaran sejarah menjadi dua kelompok, yakni pelajaran sejarah sebagai kelompok pelajaran wajib (untuk SMA/SMK) di semua kelas dan jurusan pada pembelajaran sejarah untuk kelompok peminatan (Zulkarnain, 2017).

Di ranah kajian kebijakan pendidikan maupun kebijakan akademik, dapat dijumpai beberapa hal yang dianggap menarik menjadi kajian dan pembahasan di kurikulum 2013, beberapa hal yang dapat dilihat dari kurikulum sejarah 2013 adalah temuan yang menarik untuk dijadikan kajian dalam penelitian, hal yang menarik tersebut adalah masyarakat dan peserta didik pada umumnya yang memandang mata pelajaran sejarah sebelah mata dan mata pelajaran sejarah dianggap sebagai mata pelajaran hafalan yang tidak penting, tidak bermanfaat dalam kehidupan sehari-hari karena materi yang diajarkan adalah materi hafalan berupa waktu peristiwa sejarah, nama-nama pahlawan yang sebenarnya tidak biasa digunakan dalam menganalisis situasi politik dan ekonomi di era globalisasi yang cenderung memposisikan ekonomi sebagai panglima.

Di lain hal, inovasi dan perubahan mendasar dalam kurikulum 2013 terjadi dalam banyak aspek seperti pendidikan sejarah dirancang sebagai mata pelajaran yang sarat dengan keterampilan dan cara berpikir sejarah, lalu pelajaran sejarah dikembangkan dalam proses penamaan nilai-nilai kebangsaan, pengembangan inspirasi, dan mengaitkan peristiwa sejarah nasional dengan peristiwa sejarah lokal dalam satu rangkaian Sejarah Indonesia.

Kelebihan lain dari kurikulum sejarah Indonesia SMA 2013 yakni berusaha memperkenalkan kepada peserta didik dengan lingkungan sekitar dengan harapan peserta didik mengetahui perjalanan sejarah bangsanya dan tidak melupakan budayanya, serta peserta didik menjadi pelopor kesadaran sejarah. Inovasi yang ada dalam mata pelajaran sejarah mengubah posisi pendidikan sejarah dalam banyak hal. Hal ini dapat dikembangkan sebagai dasar untuk melaksanakan berbagai inovasi dan perubahan mendasar oleh guru sejarah dalam kurikulum 2013 tersebut. 
Sementara itu, terdapat kelemahan kurikulum 2013 mata pelajaran sejarah dari sisi materi, terdapat beberapa materi yang bersingunggan antara mata pelajaran sejarah Indonesia wajib dengan sejarah peminatan bagian sejarah Indonesia, imbasnya kesamaan materi antara dua alokasi sejarah wajib dan peminatan menjadi tak terhindarkan. Kritik yang dapat disampaikan adalah penyamaan materi dari dua dimensi yang berbeda tujuan. Materi sejarah wajib cenderung mengupas materi pada analisis peristiwa sejarah pada pusaran Indonesia sementara sejarah peminatan aspeknya pada sejarah dunia secara umum dan berkaitan dengan konteks sejarah Indonesia hingga materinya pun menjadi gemuk.

Oleh karena itu, inovasi dan perubahan mendasar dalam kurikulum 2013 terbagi dalam aspek berikut: (1) pendidikan sejarah dirancang sebagai mata pelajaran yang sarat dengan keterampilan dan cara berpikir sejarah; (2) pelajaran sejarah dikembangkan dalam proses penamaan nilai-nilai kebangsaan, pengembangan inspirasi, dan mengaitkan peristiwa sejarah nasional dengan peristiwa sejarah lokal dalam satu rangkaian sejarah Indonesia. Dua hal tersebut dapat menjadi titik tolak/dasar merancang pembelajaran sejarah berkenaan dengan cara: (1) penggunaan buku teks pelajaran dan buku guru maupun media yang relevan dalam penyampaian materi; (2) kegiatan mengaitkan konten sejarah nasional dengan sejarah lokal dan sejarah dunia dalam suatu proses pembelajaran yang inovatif; (3) mengembangkan proses pembelajaran yang didasarkan pada pendekatan saintifik dalam mengembangkan kemampuan berpikir dan keterampilan sejarah. Selain itu, titik tolak/dasar tersebut membuka jalan dalam mengembangkan penilaian hasil belajar, pengembangan RPP dan memanfaatkan berbagai media belajar yang sesuai untuk mata pelajaran sejarah Indonesia yang ada di masyarakat sekitar dan juga yang bersifat penerapan teknologi informasi.

\section{Alokasi Pembelajaran Sejarah}

Berdasarkan ruang lingkup kajian sejarah tersebut, untuk pembelajaran sejarah kritis dan komprehensif, maka di dalam struktur kurikulum 2013 mata pelajaran sejarah dibagi menjadi dua bagian:

1. Sejarah Indonesia yang wajib diikuti oleh peserta didik di SMA/MA dan SMK/MAK

2. Sejarah yang masuk dalam program peminatan atau menjadi pilihan pada lintas minat di SMA/MA.

Alokasi tersebut tentu membutuhkan pengambaran yang tepat bagaimana landasan dan muasal mengapa terbitnya alokasi yang membagi sejarah Indonesia wajib dan sejarah peminatan. Pada kurikulum 2013 terdapat mata pelajaran sejarah Indonesia sebagai mata pelajaran wajib untuk jenjang Sekolah Menengah baik SMA/SMK/MA. Semua peserta didik di jenjang SMA dan yang sederajat itu harus menempuh mata pelajaran sejarah Indonesia. Yang paling pokok adalah mata pelajaran sejarah dalam rumpun ilmu sosial (IPS) bobot materi lebih dalam dengan durasi jam pelajaran yang lebih lama. 
Menurut Sardiman (2015b) desain pembagian alokasi tersebut adalah spektakuler mengingat selama ini oleh masyarakat dan juga peserta didik pada umumnya memandang mata pelajaran sejarah itu merupakan pelajaran yang tidak penting dan tidak bermanfaat dalam kehidupan keseharian. Diharapkan nantinya siswa bisa menyadari bahwa memgetahui perjalanan sejarah bangsa Indonesia dan peristiwa sejarah secara global memiliki relevansi dengan masa kini, artinya segala sesuatu yang terjadi saat ini tidak terlepas dari pengaruh peristiwa sejarah di masa lampau, serta dapat menumbuhkan rasa cinta tanah air. Keberadaan mata pelajaran sejarah Indonesia pada kurikulum 2013 akan senantiasa menjadi alat edukasi yang lebih menekankan pada perspektif dan pengembangan sikap sosial dan nilai-nilai kebangsaan bagi peserta didik. Sementara mata pelajaran sejarah pada peminatan lebih menekankan pada pengembangan keilmuan.

\section{Perubahan KI-KD Sejarah dalam Kurikulum 2013}

Sardiman (2015) mengungkapkan beberapa perubahan tertentu dan perubahan yang bersifat reaktualisasi pada kurikulum 2013 bila dibandingkan dengan kurikulumkurikulum sebelumnya. Jika ditelaah perbedaan tersebut pada rumusan SKL dan standar isi yang terkait dengan kompetensi inti (KI) dan kompetensi dasar (KD), yang paling mencolok adalah KI yang menunjukkan adanya perbedaan dibandingkan dengan KTSP atau kurikulum sebelumnya. Substansi yang dituangkan dalam KI-1, KI-2 dan KI-4 menampakan adanya perubahan. Keberadaan KI-1, KI-2 dan KI-4 bersama KI-3 dapat dimaknai sebagai jiwa kurikulum 2013 yang dimanifestasikan sejak dari dokumen sampai penerapan di kelas.

Tabel 1. Perbandingan Perubahan Kurikulum 2013 dengan Kurikulum Sebelumnya

\begin{tabular}{|c|c|c|}
\hline No & KTSP 2006 & Kurikulum 2013 \\
\hline 1 & $\begin{array}{l}\text { Standar kompetensi lulusan diturunkan } \\
\text { dari standar isi }\end{array}$ & $\begin{array}{l}\text { Standar kompetensi lulusan } \\
\text { diturunkan dari kebutuhan }\end{array}$ \\
\hline 2 & $\begin{array}{l}\text { Standar isi dirumuskan berdasarkan } \\
\text { tujuan mata pelajaran (standar } \\
\text { kompetensi lulusan mata pelajaran) yang } \\
\text { dirinci menjadi standar kompetensi dan } \\
\text { kompetensi dasar mata pelajaran }\end{array}$ & $\begin{array}{l}\text { Standar isi diturunkan dari } \\
\text { standar kompetensi lulusan } \\
\text { melalui kompetensi inti yang } \\
\text { bebas mata pelajaran }\end{array}$ \\
\hline 3 & $\begin{array}{lrr}\text { Pemisahan antara mata } & \text { pelajaran } \\
\text { pembentuk } & \text { sikap, } & \text { pembentuk } \\
\text { keterampilan, dan } & \text { pembentuk } \\
\text { pengetahuan } & & \\
\end{array}$ & $\begin{array}{l}\text { Semua mata pelajaran harus } \\
\text { berkontribusi terhadap } \\
\text { pembentukan sikap keterampilan, } \\
\text { dan pengetahuan }\end{array}$ \\
\hline 4 & $\begin{array}{l}\begin{array}{l}\text { Kompetensi diturunkan } \\
\text { pelajaran }\end{array} \\
\text { pari mata }\end{array}$ & $\begin{array}{l}\text { Mata pelajaran diturunkan dari } \\
\text { kompetensi yang ingin dicapai }\end{array}$ \\
\hline 5 & $\begin{array}{l}\text { Mata pelajaran satu dengan yang lain } \\
\text { terpisah }\end{array}$ & $\begin{array}{l}\text { Semua mata pelajaran diikat oleh } \\
\text { kompetensi inti (tiap kelas) }\end{array}$ \\
\hline
\end{tabular}

Sumber: (Paparan Wamendikbud, 14 Januari 2014). 
Tabel 2. Ruang Lingkup Kajian Sejarah Indonesia dan Peminatan di Kurikulum 2013

\begin{tabular}{|c|c|c|}
\hline No & Sejarah Indonesia & Sejarah Peminatan \\
\hline 1 & Pra Aksara & Prinsip Dasar Ilmu Sejarah \\
\hline 2 & Kerajaan Hindu & $\begin{array}{l}\text { Peradaban Awal Masyarakat Dunia dan } \\
\text { Indonesia }\end{array}$ \\
\hline 3 & Kerajaan Islam & Perkembangan Negara-Negara Tradisional \\
\hline 4 & Penjajahan Bangsa Barat & Indonesia pada Masa Penjajahan \\
\hline 5 & Pergerakan Nasional & Revolusi Besar Dunia dan Pengaruhnya \\
\hline 6 & $\begin{array}{l}\text { Proklamasi dan Perjuangan } \\
\text { Mempertahankan } \\
\text { Kemerdekaan }\end{array}$ & Kebangkitan Heroisme dan Kebangsaan \\
\hline 7 & Demokrasi Liberal & $\begin{array}{l}\text { Proklamasi, Perkembangan Negara dan } \\
\text { Bangsa Indonesia }\end{array}$ \\
\hline 8 & Demokrasi Terpimpin & $\begin{array}{l}\text { Perjuangan Mempertahankan } \\
\text { Kemerdekaan Indonesia }\end{array}$ \\
\hline 9 & Orde Baru & $\begin{array}{l}\text { Dunia Masa Perang Dingin dan Perubahan } \\
\text { Politik Global }\end{array}$ \\
\hline 10 & Reformasi & $\begin{array}{l}\text { Indonesia Saat Demokrasi Liberal dan } \\
\text { Demokrasi }\end{array}$ \\
\hline 11 & - & Indonesia pada Masa Orde Baru \\
\hline 12 & - & Indonesia pada Masa Reformasi \\
\hline 13 & - & $\begin{array}{l}\text { Indonesia, dan Dunia pada Masa Revolusi } \\
\text { Teknologi Informasi dan Komunikasi }\end{array}$ \\
\hline
\end{tabular}

\section{Tujuan, Muatan Isi dan Desain Pembelajaran Sejarah di Kurikulum 2013}

Kemendikbud (2016) melalui silabus sejarah peminatan, mata pelajaran sejarah memiliki tujuan antara lain:

1. Mengembangkan pengetahuan dan pemahaman mengenai kehidupan masyarakat dan bangsa Indonesia serta dunia melalui pengalaman sejarah bangsa Indonesia dan bangsa lain.

2. Mengembangkan rasa kebangsaan, cinta tanah air, dan penghargaan kritis terhadap hasil dan prestasi bangsa Indonesia dan umat manusia di masa lalu.

3. Membangun kesadaran tentang konsep waktu dan ruang dalam berpikir kesejarahan (historical awareness).

4. Mengembangkan kemampuan berpikir sejarah (historical thinking), keterampilan sejarah (historical skills), dan wawasan terhadap isu sejarah (historical issues), serta menerapkan kemampuan, keterampilan dan wawasan tersebut dalam kehidupan masa kini. 
5. Mengembangan perilaku yang didasarkan pada nilai dan moral yang mencerminkan karakter diri, masyarakat, dan bangsa.

6. Menanamkan sikap berorientasi kepada kehidupan masa kini dan masa depan berdasarkan pengalaman masa lampau.

7. Memahami dan mampu menangani isu-isu kontroversial untuk mengkaji permasalahan yang terjadi di lingkungan masyarakatnya.

8. Mengembangkan pemahaman internasional dalam menelaah fenomena aktual dan global.

Kemendikbud (2016) menyatakan muatan isi mata pelajaran sejarah mengembangkan peserta didik agar memiliki kemampuan intelektual dan kecemerlangan akademik, pewaris nilai-nilai kebangsaan dan memiliki kepedulian terhadap permasalahan kehidupan masyarakat dan bangsa pada masa kini dan masa depan. Berdasarkan hal tersebut, apa yang diungkapkan oleh kemendikbud menyasar pada harapan agar kajian sejarah menjadi nilai-nilai yang mapan untuk mewujudkan kehidupan berbangsa dan bernegara. Di samping itu, pembelajaran sejarah dirancang untuk membekali peserta didik dengan keterampilan dan cara berpikir sejarah, membentuk kesadaran sejarah, menumbuhkembangkan nilai-nilai kebangsaan, mengembangkan inspirasi, dan mengaitkan peristiwa lokal, nasional dengan peristiwa global dalam satu rangkaian sejarah.

\section{SIMPULAN}

Posisi mata pelajaran sejarah dalam kurikulum 2013 dimaknai sebagai mata mata pelajaran yang paling berpotensi dan berkesempatan besar untuk menanamkan kesadaran sejarah sehingga mampu mengadopsi nilai-nilai kebangsaan dan penanaman nilai karakter melalui sejarah Indonesia (wajib) maupun sejarah pada kelompok peminatan, yang harus diambil oleh peminatan ilmu sosial (IPS) dan ilmu alam (IPA). Ruang lingkup kajian sejarah wajib dan peminatan bila dilihat secara komprehensif telah sesuai dengan kebutuhan peserta didik, namun tentunya ada kelemahan seperti materi yang tumpang tindih pada sejarah Indonesia. Kelompok sejarah wajib dan peminatan pada evolusi standar kompetensi (SK) pada kurikulum sebelumnya menjadi kompetensi inti (KI) yang menunjukan perbaikan tujuan pencapaian kompetensi.

\section{DAFTAR PUSTAKA}

Haniah, A. (2017). Pelaksanaan Pembelajaran Sejarah dengan Kurikulum 2013. Universitas Negeri Yogyakarta.

Hasan, H. (2007). Kurikulum Pendidikan Sejarah Berbasis Kompetensi. Retrieved from http://file.upi.edu/Direktori/FPIPS/JUR._PEND._SEJARAH/19440310196710 1-SAID_HAMID_HASAN/Makalah/Pendidikan_Sejarah_Berbasis_Kompete nsi.pdf

Kemendikbud. (2016a). Silabus Sejarah Peminatan Kurikulum 2013. 
Kemendikbud. (2016b). Silabus Sejarah Wajib Kurikulum 2013.

Mastur. (2017). Implementasi Kurikulum 2013 dalam Pelaksanaan Pembelajaran di SMP. Jurnal Inovasi Teknologi Pendidikan, 4(1), 50. https://doi.org/ 10.21831/ jitp.v4i1.10131

Rochgiyanti. (2014). Posisi Materi Sejarah di Tingkat Sekolah Menengah Pertama Pada Kurikulum 2013. Sejarah dan Budaya, 8(2). Retrieved from http://dx.doi.org/ $10.17977 /$ sb.v8i2.4771

Sardiman. (2015a). Menakar Posisi Sejarah Indonesia Pada Kurikulum 2013. Istoria: Jurnal Pendidikan dan Ilmu Sejarah, 11(1). Retrieved from https:// doi.org/10.21831/istoria.v11i2.7555

Sardiman. (2015b). Pembelajaran Sejarah dan Nilai-nilai Kepahlawanan. Retrieved from http://staff.uny.ac.id/sites/default/files/Sejarah dan Nilai-nilai Kepahlwn.pdf

Sayyidah, S. (2014). Implementasi Kurikulum 2013 Mata Pelajaran Sejarah Wajib Kelas X di SMA MTA Surkarta Tahun Ajaran 2014/2015. Skripsi. Universitas Sebelas Maret.

Subandi. (2014). Pengembangan Kurikulum 2013. Pendidikan dan Pembelajaran Dasar, 1(1). Retrieved from https://adoc.tips/pengembangan-kurikulum-2013-studianalitis-dan-subtantif-keb.html

Sugiyono. (2009). Metode Penelitian Kuantitatif, Kualitatif dan RED. Bandung: Alfabeta.

Sulasman. (2014). Metodologi Penelitian Sejarah. Bandung: Pustaka Setia.

Sutarman, E. (2015). Implementasi Kurikulum 2013 dalam Pembelajaran Sejarah di SMAN 1 Rembang Tahun Ajaran 2014/2015. Skripsi. Universitas Negeri Semarang.

Zed, M. (2004). Metode Penelitian Kepustakaan. Jakarta: Yayasan Obor Indonesia.

Zulkarnain. (2017). Kebijakan Kurikulum Sejarah di Sekolah Menegah Atas. Universitas Negeri Yogyakarta. 